\title{
CARDIOGENIC SHOCK POST ACUTE MYOCARDIAL INFARCTION ASSOCIATED WITH A NON REPERFUSION CORONARY ARTERY PHENOMENON
}

\author{
CHOQUE CARDIOGÊNICO APÓS INFARTO AGUDO DO MIOCÁRDIO \\ ASSOCIADO AO FENÔMENO DE NÃO REPERFUSÃO DA ARTÉRIA CORONÁRIA
}

\author{
Poliana Rodrigues Alves DUARTE ${ }^{1}$; Camila Leal GUIMARÃES ${ }^{2}$; \\ Omar Pereira de Almeida NETO ${ }^{3}$; João Lucas O' CONNEL ${ }^{4}$; Elmiro Santos RESENDE ${ }^{4}$ \\ 1. Enfermeira, Doutora em Ciências da Saúde, Universidade Federal de Uberlândia - UFU, Uberlândia, MG, Brazil; 2. Discente do \\ Curso de Graduação em Medicina - UFU, Uberlândia, MG, Brazil; 3. Professor, Doutor, Faculdade de Enfermagem - UFG, Jataí, GO, \\ Brazil; 4. Professor, Doutor, Faculdade de Medicina - UFU, Uberlândia, MG, Brazil.
}

\begin{abstract}
Cardiogenic shock is a state of systemic tissue hypoperfusion resulting from a primary cardiac dysfunction. When it occurs simultaneously to a non reperfusion coronary artery phenomenon, prognosis worsens and mortality chances increases. This paper reports the case of a patient presenting cardiogenic shock after acute myocardial infarction - AMI concurrently with no-reflow phenomenon. It is a clinical case, cares and main aspects in treatment for simultaneous cardiogenic shock and no-reflow phenomenon are discussed, pointing out the relevance of early detection of these two clinical situations as to correct their deriving dysfunctions and ensure the best possible prognosis to the patient.
\end{abstract}

KEYWORDS: Cardiogenic Shock. Acute Myocardial Infarction. Cardiology.

\section{INTRODUCTION}

Cardiogenic shock is characterised by decreased tissue perfusion due to cardiac muscle failure in providing adequate oxygen and nutrients to the body's needs (HOCHMAN, J. S ; REYENTOVICH, A., 2015). In spite of the breakthroughs for diagnostic methods and treatment of heart disease in the past decades, cardiogenic shock still presents high levels of mortality, reportedly at about 50\%. Cardiogenic shock can happen in various clinical situations relating to low output; however, its main cause is the loss of cardiac muscle tissue after acute myocardial infarction (RANGEL, F. O. D., 2013).

Patients who undergo angioplasty and present with cardiogenic shock have a death risk even higher (up to 70\%) and a poor prognosis when simultaneously present with reflow, which is also known as a phenomenon of non-reperfusion of the coronary arteries. This phenomenon results mainly from the tissue and microvascular damage from myocardial ischemia, especially if coronary occlusion persists longer than 45 minutes. It happens as an acute and severe reduction of coronary flow (TIMI 0 to TIMI 2) after clearing a coronary artery, which is a critical situation with high mortality risk, and has as its most intriguing feature the unpredictability. Often, the first clinical manifestation is insidious chest pain with continuous and increasing trends, followed by electrocardiographic changes in the ST/T segment and arrhythmias (KAUL, S. 2014).

As the patient's clinical, hemodynamic, and angiographic symptoms worsen over time, an early diagnose is required for both cardiogenic shock and no-reflow phenomenon, as well as early aggressive therapy to ensure better and faster reversal of the clinical condition. (ALTAYYAR, S., et al. 2014).

\section{CASE REPORT}

Male patient, 56, farm worker, former smoker, sent to the medical service due to a context of chest pain, sudden onset, with $\Delta \mathrm{t}=8$ hours, and high intensity (8/10); of the burning type, poorly localized, with radiating to the upper limbs and associated with nausea and dyspnea. Then patient reported untreated dyslipidemia and use of Sildenafil in that morning. After undergoing electrocardiograms, he was diagnosed with inferodorsal AMI with ST segment elevation.

Since he was also experiencing angina at rest as well as clinical and hemodynamic instability, the patient underwent urgent cardiac catheterization on that same day. A Coronary Angioplasty (Figure 1) with implantation of two stents into the artery circumflex was performed. However, after implantation of stents, the patient's coronary flow decreased (TIMI I) and his clinical, electrical, and hemodynamic conditions worsen significantly. Initially, it was decided on coronary dissection proximal or distal to the stents, and therefore, two 
stents were implanted. As the patient's clinical and angiographic outcomes remained unstable, it was compatible with "no-reflow" (phenomenon of nonreperfusion of the coronary arteries). a)

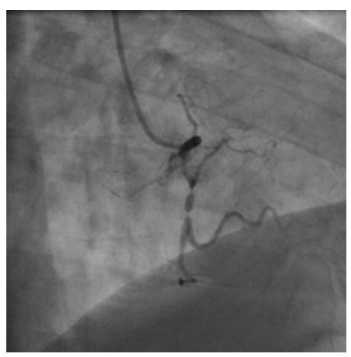

c)

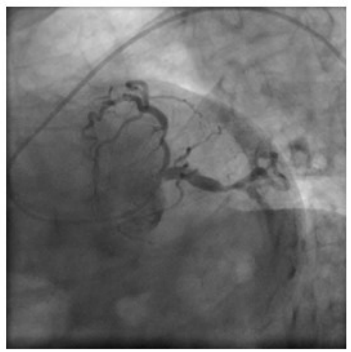

b)

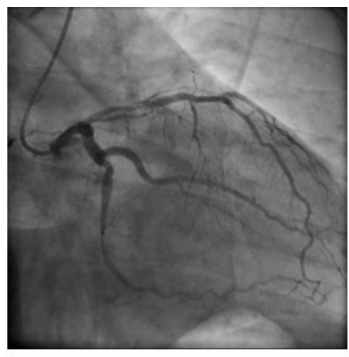

d)

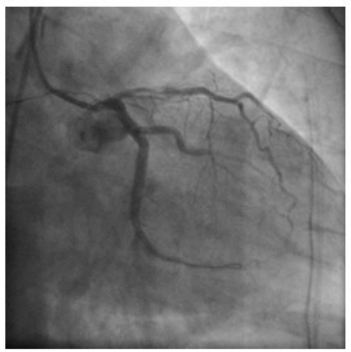

Figure 1. a) right coronary angiography showing the nondominant right coronary artery, with long and significant stenosis in its middle segment. b) Coronary angiography in left anterior oblique projection right flow, showing significant stenosis in the distal segment of the circumflex artery and severe stenosis in the proximal segment of the anterior descending artery. c) Coronary angiography in left anterior oblique projection left caudal showing significant stenosis in the middle segment of the circumflex artery, involving the origin of the first major marginal. d) left coronary angiography after coronary angioplasty with implantation of two stents to circumflex artery.

In the following day, as the cardiogenic shock symptoms remained, the patient undergone an additional Coronary Angioplasty with implantation of two stents for the anterior descending artery (Figure 2) and an Intra-aortic balloon pump. After the procedure, good angiographic and III TIMI flow outcomes were observed (Figure 3).
The patient remained hospitalized in the Intensive Cardiac Care Unit and showed improved clinical and hemodynamic results due to the intensive care and medication targeted at increasing myocardial perfusion. Currently, the patient is under outpatient monitoring and takes part in a multicenter study.

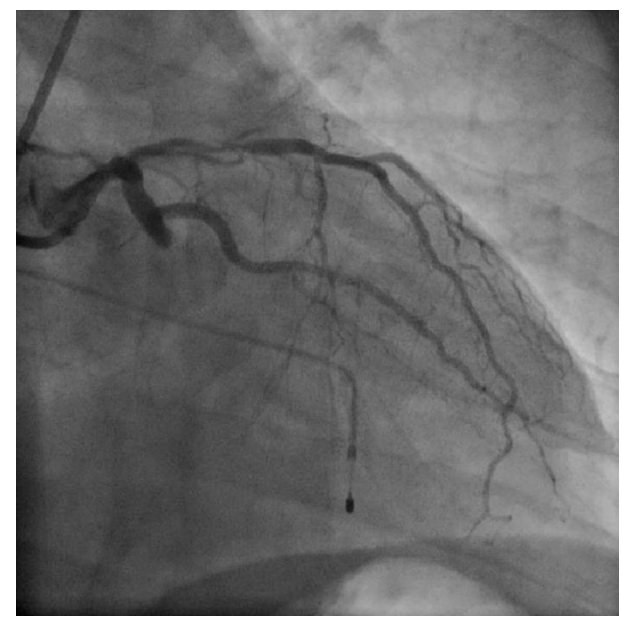

Figure 2. A Patient's coronary Angiography image in anterior oblique projection right flow, showing total occlusion of the circumflex artery stent in the middle segment of the vessel and important and long stenosis in the proximal segment of the anterior descending artery. 


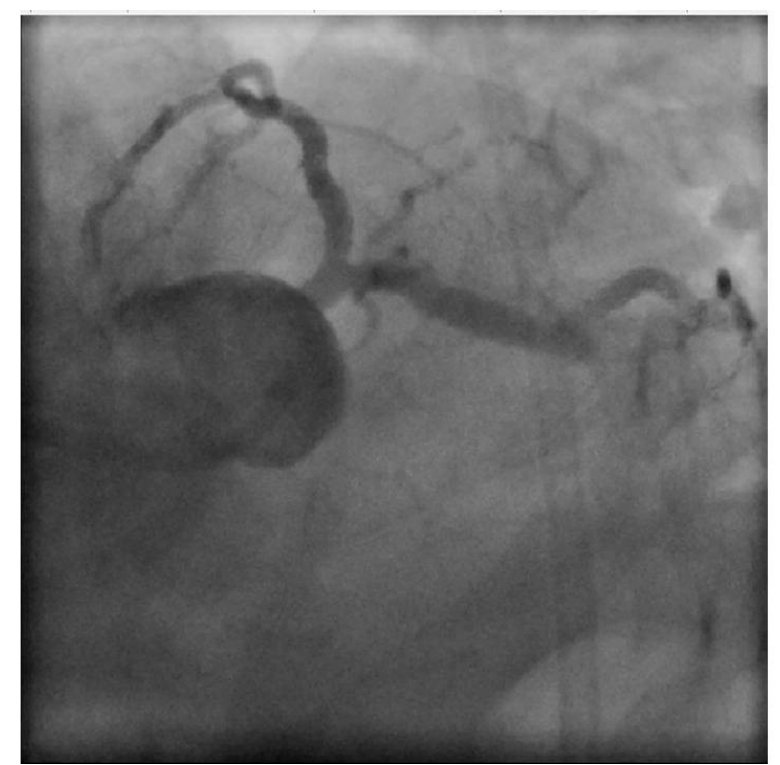

Figure 3. Coronary angiography left showing significant improvement in the stenoses in the ostium and proximal segment of the anterior descending artery, and occlusion of the circumflex artery in middle segment.

As previously discussed, a prompt diagnosis is the key to achieving the best outcome for the patient who is in cardiogenic shock, alongside with immediate therapeutic support and rapid revascularization of coronary arteries on those patients who have the acute myocardial infarction as aetiology (Xiushui, MR 2015). The use of aortic balloon counterpulsation brings several benefits for the patient in cardiogenic shock, including: improvement of coronary and peripheral perfusion through the balloon inflation during ventricular diastole and increased left ventricular performance by decreasing acute afterload due to balloon deflation during systole. (DUBEY, L. 2011). Thus, in the case presented here, the procedure of simultaneous intervention in Anterior Descending Artery and Circumflex Artery with implantation of six stents, was required due to the high risk of death or perpetuated myocardial ischemia, caused by significant stenoses found at diagnosis. Furthermore, it is important to highlight the relevance of correct positioning and use of aortic balloon counterpulsation, which was responsible for the significant improvement in the patient's hemodynamic status.

Regarding drug therapy, there are no specific studies in subgroups of patients with post would cardiogenic shock. Nonetheless, literature reinforces the importance of using drugs that increase myocardial perfusion (DUBEY, L. 2011). It is therefore recommended the use of vasoconstrictors associated with inotropic agents, to ensure the coronary and systemic infusions to the implant balloon counterpulsation (RANGEL, F. O. D., 2013). Thus, as the patient showed clinical signs of hypoperfusion and hypotension, we chose to use a powerful vasoconstrictor noradrenaline, and a powerful inotropic drug dobutamine.

The treatment for the phenomenon of nonreperfusion of the coronary arteries should consider myocardial ischemia duration. If the coronary occlusion lasts less than 45 minutes, the no-reflow phenomenon is mainly caused by the distal embolization of thrombi and components of atherosclerotic plaque. Thus, treatment includes manual aspiration of thrombus and the use of antiplatelet agents. However, if the coronary obstruction persists for more than 45 minutes, the no-reflow phenomenon results especially from tissue and microvascular damage caused by the myocardial ischemia. The therapeutic options in this case include the use of adenosine, nicorandil and verapamil (KAUL, S. 2014). In this case, the option was to use intracoronary adenosine due to its vasodilating action on the coronary arteries and their anti-inflammatory effect, which are responsible for reducing the infarct size and the area affected by the phenomenon of "no-reflow".

Early mortality of patients with cardiogenic shock concomitant to the phenomenon of nonreperfusion of the coronary arteries is still expressively high, so there is a need to expand knowledge in this area, including improved treatment strategies and adjuvant therapies. 
RESUMO: O choque cardiogênico é um estado de hipoperfusão sistêmica do tecido resultante de uma disfunção cardíaca primária. Quando ocorre simultaneamente a este fenômeno a não reperfusão da artéria coronária, o prognóstico piora e as chances de mortalidade aumentam. Este artigo relata o caso de um paciente que apresentou choque cardiogênico após infarto agudo do miocárdio - IAM e simultaneamente com fenômeno sem refluxo. Trata-se de um caso clínico, onde são abordados os principais aspectos no tratamento do choque cardiogênico simultâneo e do fenômeno de não refluxo, destacando a relevância da detecção precoce dessas duas situações clínicas para corrigir suas disfunções derivadas e assegurar o melhor prognóstico possível para o paciente.

PALAVRAS CHAVE: Choque Cardiogênico. Infarto Agudo do Miocárdio. Cardiologia.

\section{REFERENCES}

ALTAYYAR, S., et al. Intra-aortic balloon pump in patients with cardiogenic shock complicating myocardial infarction: a systematic review and meta-analysis of randomized trials (protocol). Systematic Reviews.

London, v. 3, n. 24. March, 2014.

HOCHMAN, J. S., REYENTOVICH, A. My approach to the management of cardiogenic shock. Trends in Cardiovascular Medicine. Philadelphia, v. 25, n. 6, p. 561-562. August, 2015.

RANGEL, F. O. D. Abordagem contemporânea do choque cardiogênico. Jornal Brasileiro de Medicina. Rio de Janeiro, v. 101, n. 2, p. 19-24. March, 2013.

KAUL, S. et al. The "no-reflow" phnomenon following acute myocardial infarction: mechanism and treatment options. American Journal of Cardiology. Philadelphia, v. 64, n. 2, p. 77-85. May, 2014.

https://doi.org/10.1016/j.jjcc.2014.03.008

DUBEY, L. et al. Cardiogenic shock complicating acute myocardial infarction - a review. An International Journal of Cardiology. Leuven, v. 66, n. 6, p.691-699, 2011.

XIUSHUI, M. R. Cardiogenic Shock Treatment and Management. Medscape. New York. December, 2015. 